\title{
Stability of a sand spit due to dredging in an adjacent creek
}

Rupali S. Patgaonkar, D. Ilangovan, P. Vethamony*, M. T. Babu, S. Jayakumar and M. D. Rajagopal

National Institute of Oceanography, Dona Paula, Goa - 403 004, India ( ${ }^{*}$ correspondending author, e-mail: mony@darya.nio.org, Ph: 91(0)832-2450473, Fax: 91(0)832-2450604)

\begin{abstract}
The Jatadharmohan creek lies between Mahanadi and Devi Rivers along the Orissa coast and it is separated from the sea by an elongated sand spit. It was proposed to mine a volume of $15 \times 10^{6} \mathrm{~m}^{3}$ of sand from the creek for land filling, but maintaining the spit intact. For this, the stability of sand spit is studied with different criteria. The results confirm that the creek mouth is a near permanent zone of deposition. The model results obtained for various depth scenarios show that the magnitude of currents would increase considerably when depth is increased by $7.0 \mathrm{~m}$ and marginally for further increase in depth by $10.0 \mathrm{~m}$. Accordingly, a dredging scheme has to be designed without affecting the spit stability. Considering the existing hydrodynamics in the creek system, it is recommended that a bed slope of 1:6 $\left(9.5^{\circ}\right)$ be maintained during dredging, which is much less than $13.75^{\circ}$ - the evaluated critical slope at the site when seepage flow is parallel to the bed slope. It is observed during monitoring that the creek is very productive, and the sand spit is totally intact.
\end{abstract}

Keywords: Jatadharmohan creek, dredging, sand spit stability, hydrodynamic modelling, safety factor 


\section{Introduction}

The Jatadharmohan creek (hereinafter referred to as JMC) is a tidal creek oriented in the NE-SW direction (Fig. 1) and lies to the south of Paradip, along the east coast of India. This creek runs almost parallel to the shoreline for about $9 \mathrm{~km}$, and has an average width of $0.7 \mathrm{~km}$. There are a number of linear to curvy sand ridges on both sides of the creek. Based on their orientation (more or less parallel to the present shoreline), these sand ridges are interpreted as the remnants of beach-dune ridges representing the former shoreline position.

JMC is separated from the sea by an elongated sand spit. There are references to several sand spits along the east coast of India in the Quaternary Deltas of India edited by Vaidyanadhan (1991). The sandspit adjacent to JMC has a maximum width of $660 \mathrm{~m}$. The tip of this landform is highly subject to hydrodynamic forces from both the creek and sea sides, leading to progression and degradation. It is noticeable from satellite images that considerable deposition is taking place on the spit mouth (NIO Report, 1998) leading to spit extension.

It was proposed to mine a volume of $15 \times 10^{6} \mathrm{~m}^{3}$ sand from the $\mathrm{JMC}$ for land filling in an adjacent region (NIO Report, 1998) and a volume of $13 \times 10^{6} \mathrm{~m}^{3}$ sand has actually been mined. Sand mining from the JMC is preferred not only for the availability of good quality land filling material, but also for the reasons such as shallow depth, low priority reach as far as potential for fisheries, vegetation and benthic communities are concerned. A detailed investigation related to bathymetry, high water line (HWL), low water line (LWL), currents, geotechnical properties of sediments, etc. of the JMC has been carried out under the project "Geo-technical and water quality studies of Jatadharmohan creek, Paradip, Orissa" (NIO Report, 1999). General bathymetry, geomorphology, coastal configuration and environmental conditions prevailing in the JMC-spit zone indicate that the creek could be considered as a major sand sink - a suitable candidature site for sand mining. Further, wave refraction results show that the coastal region consisting of sand spit and JMC mouth is a divergence zone, irrespective of any particular wave direction and wave period (NIO Report, 1998). This feature favours deposition of sedimentary material from the upper and lower reaches of the coast. This region was again modelled by removing the sand spit. The model results confirm that the creek mouth 
is a near permanent zone of divergence or deposition. The net northward movement of sediment supplies sand to the spit. In this context, a study was carried out to evaluate the stability of sand spit when a quantity of $15 \times 10^{6} \mathrm{~m}^{3}$ sand is dredged from the creek.

\section{Environmental Conditions}

JMC is a very shallow water body with water depths ranging from 0.5 to $2.5 \mathrm{~m}$. The ridge complex is very prominent immediately landward of the JMC mouth. This particular large patch of sand ridge complex is surrounded by low-lying tidal flats, which are criss-crossed by smaller tidal inlets. These tidal flats are built of silt and clayey sediments and are partially emerged (NIO Report, 1999). Bathymetric data were acquired by using continuous echosounding at $250 \mathrm{~m}$ line spacing in the Jatadharmohan creek. The analysis shows that the topography of this area is steeply sloping down towards deeper depths, thus depicting a steep gradient. The isobaths in this region are running parallel to the coast. The echogram of inner region indicates rugged topography associated with scour marks. This topography might have been caused by erosional environment due to heavy wave breaking.

It is important to understand various hydrodynamic forces acting on the coastal-sand spit - JMC region. For this purpose, we used the data collected off Paradip during May 1996 - June 1997, covering both the southwest and northeast monsoons.

Current measurements were carried out during 22 May-10 June1996 by deploying 2 RCM-7 current-meters ( $1 \mathrm{~m}$ below the sea surface and $2 \mathrm{~m}$ above the bottom) at the location $20^{\circ} 8.46^{\prime} \mathrm{N}$; $86^{\circ} 44.51^{\prime} \mathrm{E}$ (depth=30 m) and two DCM-12 currentmeters at the locations $20^{\circ} 11.34^{\prime} \mathrm{N}, \quad 86^{\circ} 40.13^{\prime} \mathrm{E}$ (depth=15 m) and $20^{\circ} 08.58^{\prime} \mathrm{N}, \quad 86^{\circ} 39.98^{\prime} \mathrm{E}$ (depth=22 m). For obtaining the flow field during winter season, two RCM-7 currentmeters were deployed at all the above locations during 12 November 1996 - 20 January 1997. However, we have used the data collected inside the creek during April 1999 for simulation.

The analysis shows that surface current speed varies from 10 to $40 \mathrm{~cm} / \mathrm{s}$ during summer monsoon and the currents are consistently easterly to northeasterly with no southerly components. During winter monsoon, the surface current speeds range between 70 and $80 \mathrm{~cm} / \mathrm{s}$ in the northeasterly direction and bottom currents at around 
$45 \mathrm{~cm} / \mathrm{s}$. As surface currents are primarily run by monsoon winds, tidal signature is more pronounced in the bottom currents.

Tides of Paradip are semi-diurnal type. The mean low water spring, with reference to the chart datum, is $0.71 \mathrm{~m}$ and mean high water spring $2.58 \mathrm{~m}$. The water level variations observed at the current meter mooring sites match closely with those predicted for Paradip Port.

A Directional wave rider buoy was deployed on 22 May 1996 at the location $20^{\circ} 08.57^{\prime} \mathrm{N}, 86^{\circ} 44.67^{\prime} \mathrm{E}$ (water depth= $30 \mathrm{~m}$ ), and wave data collection was continued upto 18 January 1997. Significant wave heights vary from 0.50 to $3.41 \mathrm{~m}$ and the maximum wave heights upto $6.3 \mathrm{~m}$. These wave information have been used in the wave refraction model to identify regions of divergence and convergence.

Wind speed is very low (<2 m/s) during January-March and high $(6-8 \mathrm{~m} / \mathrm{s})$ during SW monsoon. The analysis of formation and movement of cyclone, depression and severe storm over the Bay of Bengal from the 80 years data shows that the formation is negligible during January-March, high during May to July and very high during October and November. During a period of 12 years, nearly 16 cyclones/ depressions crossed the coast very close to Paradip. Overall analysis of cyclones suggest that major damage due to direct hit of very severe cyclonic storms near Paradip coast is less likely.

\section{Methodology, Results and Discussion}

The following criteria have been applied to evaluate stability of the sand spit when a quantity of $15 \times 10^{6} \mathrm{~m}^{3}$ sand is dredged from the creek:

(i) Tidal current circulation in the creek before and after dredging

(ii) Side slope and dredging depth

(iii) Hydraulic gradient and pore water flow 


\subsection{Tidal current circulation in the creek before and after dredging}

The circulation pattern in the creek before and after dredging has been studied using a numerical model (TIDAL, 1994). A rectangular domain of $5200 \mathrm{~m} \mathrm{X} 1500 \mathrm{~m}$ has been chosen with a grid size of $100 \mathrm{~m}$ X $100 \mathrm{~m}$. Tide elevations, currents, bathymetry and winds measured at the confluence point are given as input to the model. The simulated zonal and meridianal current components ( $u$ and $v$ respectively) have been compared with those of measured currents (on 22 April 1999) and the match is very good (Fig. 2).

The simulated flood and ebb currents for the existing bathymetry (E) range up to $0.68 \mathrm{~m} / \mathrm{s}$ and $0.56 \mathrm{~m} / \mathrm{s}$, respectively (Figs. $3 \& 4$ ). The maximum currents are noticed in the narrow region of the creek. A few more runs have been made with new bathymetry $(E+7 \mathrm{~m}, \mathrm{E}+8 \mathrm{~m}$ and $\mathrm{E}+10 \mathrm{~m})$ for deriving the modified circulation pattern after dredging to $7 \mathrm{~m}, 8 \mathrm{~m}$ and $10 \mathrm{~m}$ from the existing bed level (Example: Fig. 5). The results show that magnitude of currents for the new bathymetry increases, but only marginally (Table 1). Hence, the marginal change in current pattern will not affect the spit stability.

\subsection{Side slope and dredging depth}

The analysis of sediment samples collected from the JMC shows that the texture is predominantly sandy, and the grain size varies from fine to medium. The bore-hole samplings carried out to a depth of $30 \mathrm{~m}$ below the creek bed at 18 locations also show the presence of fine to medium sand up to $14 \mathrm{~m}$ depth and clayey soils beyond that. Geo-technical calculations have been carried out assuming that sand is the material present to a depth of $14 \mathrm{~m}$.

The maximum stable slope is equal to friction angle, $\phi$ in coarse-grained soil in the absence of seepage. The same in the case of seepage parallel to the slope is approximately one-half the friction angle, i.e, $\phi / 2$.

In JMC area, the lowest friction angle $(\phi)$ is $27.5^{\circ}$ for the soils up to $16 \mathrm{~m}$ (NIO Report, 1999). The maximum tidal range in the region is $1.87 \mathrm{~m}$. Hence, during low water levels there is a possibility of seepage parallel to the slope and this restricts the maximum stable slope to $\phi / 2$ i.e. $13.75^{\circ}$. This slope is stable only in static water 
condition. Considering the existing hydrodynamics in the creek system, the suitable bed slope to be maintained during dredging on both the sides of the creek $t$ is $1: 6$, i.e. $9.5^{\circ}$, which is much less than $13.75^{\circ}$.

The stability analysis is carried out for this slope (1:6) using GALENA 4.0 (GALENA, 2003). The GALENA system considers slope stability assuming that the overall geometry remains the same and it is the slope surface that requires change. In GALENA, the overall geology is defined, including the material properties. Material above the slope surface is ignored since this has been already removed. Thus, GALENA enables a large number of analyses to be undertaken without the need to redefine the model each time.

The stability of slope is studied using Bishop simplified method of analysis incorporated in GALENA. We have considered circular failure surfaces assuming that the material on the scale of the slope is non-cohesive, comparatively homogeneous and isotropic.

The analysis is carried out at 5 critical sections spread over in the JMC (Fig. 6). The sections are selected at the points of abrupt change in cross section or direction of flow. A particular section may pass through one or more boreholes. At each section, 7 material profiles are used and density and $\phi$ values at every $2 \mathrm{~m}$ depth are specified. In slope stability analysis, lower $\phi$ values and higher density are critical and accordingly, appropriate borehole is considered to represent the material at each section.

The shear strength parameters of the sandy deposits have been found out using the following relation (Muromachi, 1974):

$$
\phi=20^{\circ}+2.5\left(\mathrm{~N}_{30}\right)^{0.5}
$$

where,

$$
\begin{gathered}
\phi=\text { angle of internal friction and } \\
N_{30}=\text { penetration resistance }
\end{gathered}
$$

$\mathrm{N}_{30}$ values are obtained from the Standard Penetration Test (SPT) as the number of blows required to drive the sampler from $15 \mathrm{~cm}$ to $45 \mathrm{~cm}$. The observed $\mathrm{N}_{30}$ values 
have been corrected for water table and over burden pressure using the following relations:

a) Water table correction:

$$
N_{\text {cor }}=15+\left(N_{\text {obs }}-15\right) / 2, \quad \text { for } N_{\text {obs }}>15
$$

b) Overburden correction:

$$
\begin{aligned}
& \mathrm{N}_{\text {cor }}=\mathrm{N}_{\text {obs }} \times 350 /(\sigma+70) \\
& \text { where, } \sigma=\text { overburden pressure }
\end{aligned}
$$

The critical circular failure surface is the one for which factor of safety is the least. This is arrived at by trial and error method assuming two end points and radius for the failure surface. The critical safety factor values for the five sections (Fig. 6) are given in Table 2. The critical failure surface for the most critical section is shown in Fig. 7. As the factor of safety (Table 2) for all the sections are above 3.0, we can confirm that the suggested slope is stable. The dredging scheme is schematically shown in Fig. 8. The quantity of material that can be dredged from the creek for different depths from the IMSL has been computed by taking the difference between the existing water level and the new water levels. The quantity varies from $14.0 \times 10^{6}$ to $19.1 \times 10^{6} \mathrm{~m}^{3}$ depending upon depth of dredging (Table 1). Though the proposed sand for reclamation is approximately $15 \times 10^{6} \mathrm{~m}^{3}$, only $13 \times 10^{6} \mathrm{~m}^{3}$ has been dredged. In the model entire volume of water in the creek has been taken into account for computing volume, but dredging need not be done in the entire body of creek. After dredging, regular monitoring was carried out to assess the stability of the spit, and it was observed that the sand spit is intact.

\subsection{Hydraulic gradient and pore water flow}

As water levels in the creek and the sea are almost the same, the level of water table in the spit remains the same before and after dredging. Therefore, no hydraulic gradient exists between the creek and the sea. Further, sand materials are fully in saturated condition and will not have any significant upward pore water flow due to seepage. Hence, there will not be any possibility for the formation of quick sand condition after dredging. Also, there will not be any increase in the hydrostatic 
pressure in the vicinity other than the dredged segment. This increase is very nominal, and it would act only on the sediment grains lying on the channel bed. As there are no coastal structures or retaining walls existing in the vicinity, there will not be any impact due to this marginal increase in the hydrostatic pressure.

\section{Conclusions}

Sand mining from the JMC is preferred since it is shallow and is of low priority reach as far as potential for fisheries, vegetation and benthic communities are concerned. The increase in the hydrostatic pressure due to dredging is very nominal, and as such there will not be any impact to the sand spit. Dredging should be well within LWL in the creek system and edges of dredging zone should be $700 \mathrm{~m}$ away from fragile tip of sand spit in the confluence zone. Bed slope at both the sides of creek shall be maintained not less than 1:6 slope. After deepening, it is found that JMC is very productive and the sand spit is totally intact.

\section{Acknowledgement}

The authors thank Director, NIO, for providing facilities and constant encouragement to carry out this work. They express their gratitude to all the participants who were involved in data collection off Paradip. The officials of Indian Oil Corporation are acknowledged for funding the project. 


\section{References}

Bharali., Rath, B. S., Sarma, R.,1991. A brief review of Mahanadi delta and the deltaic sediments in Mahanadi basin. In Memoirs of Geological Society of India, Bangalore, No. 22, pp. 31 - 49.

Budhu, M., 1999. Soil mechanics and foundations. John Wiley and Sons, Inc.

NIO Report, 1998. Comprehensive environmental impact assessment for the proposed marine facilities for the Eastern India Refinery at Paradip, Orissa. Technical Report No: NIO/ SP- 7/1998, National Institute of Oceanography, India, July.

NIO Report, 1999. Geo-technical, bathymetry and water quality studies of Jatadharmohan Creek, Paradip, Orissa. Technical Report No: NIO/SP- 26/1999, National Institute of Oceanography, India, September.

User Guide, 1994. TIDAL - a software tool for dynamic analysis of flow and water quality in large, shallow water bodies. Version 2.50, Analytical and Computational Research Inc, USA.

User Guide, 2003. GALENA slope stability analysis system users' guide. Clover Associates Pvt. Ltd., Australia.

Vaidyanadhan, R., 1991. Quaternary Deltas of India, Memoir 22, Geological Society of India, Bangalore. 
Table 1

Maximum tidal currents and quantity of dredged material

\begin{tabular}{|c|l|c|c|c|c|}
\hline $\begin{array}{c}\text { S. } \\
\text { No. }\end{array}$ & Depth (m) & $\begin{array}{c}\text { Flood } \\
\text { current } \\
(\mathbf{m} / \mathbf{s})\end{array}$ & $\begin{array}{c}\text { Ebb } \\
\text { current } \\
(\mathbf{m} / \mathbf{s})\end{array}$ & $\begin{array}{c}\text { Vol. of water } \\
\left(\times \mathbf{1 0}^{\mathbf{6}} \mathbf{m}^{\mathbf{3}} \mathbf{)}\right.\end{array}$ & $\begin{array}{c}\text { Quantity of } \\
\text { dredged material } \\
\left(\times \mathbf{1 0}^{\mathbf{6}} \mathbf{m}^{\mathbf{3}} \mathbf{)}\right.\end{array}$ \\
\hline 1 & Existing (E) & 0.68 & 0.56 & 3.7 & - \\
\hline 2 & E+7.0 & 1.00 & 0.82 & 17.7 & 14.0 \\
\hline 3 & E+8.0 & 1.04 & 0.88 & 19.7 & 16.0 \\
\hline 4 & E+10.0 & 1.18 & 0.89 & 22.8 & 19.1 \\
\hline
\end{tabular}

Table 2

Factor of safety for the 5 critical sections

\begin{tabular}{|c|c|}
\hline Section & Factor of safety \\
\hline Section 1 & 4.01 \\
\hline Section 2 & 4.27 \\
\hline Section 3 & 3.60 \\
\hline Section 4 & 3.56 \\
\hline Section 5 & 3.40 \\
\hline
\end{tabular}

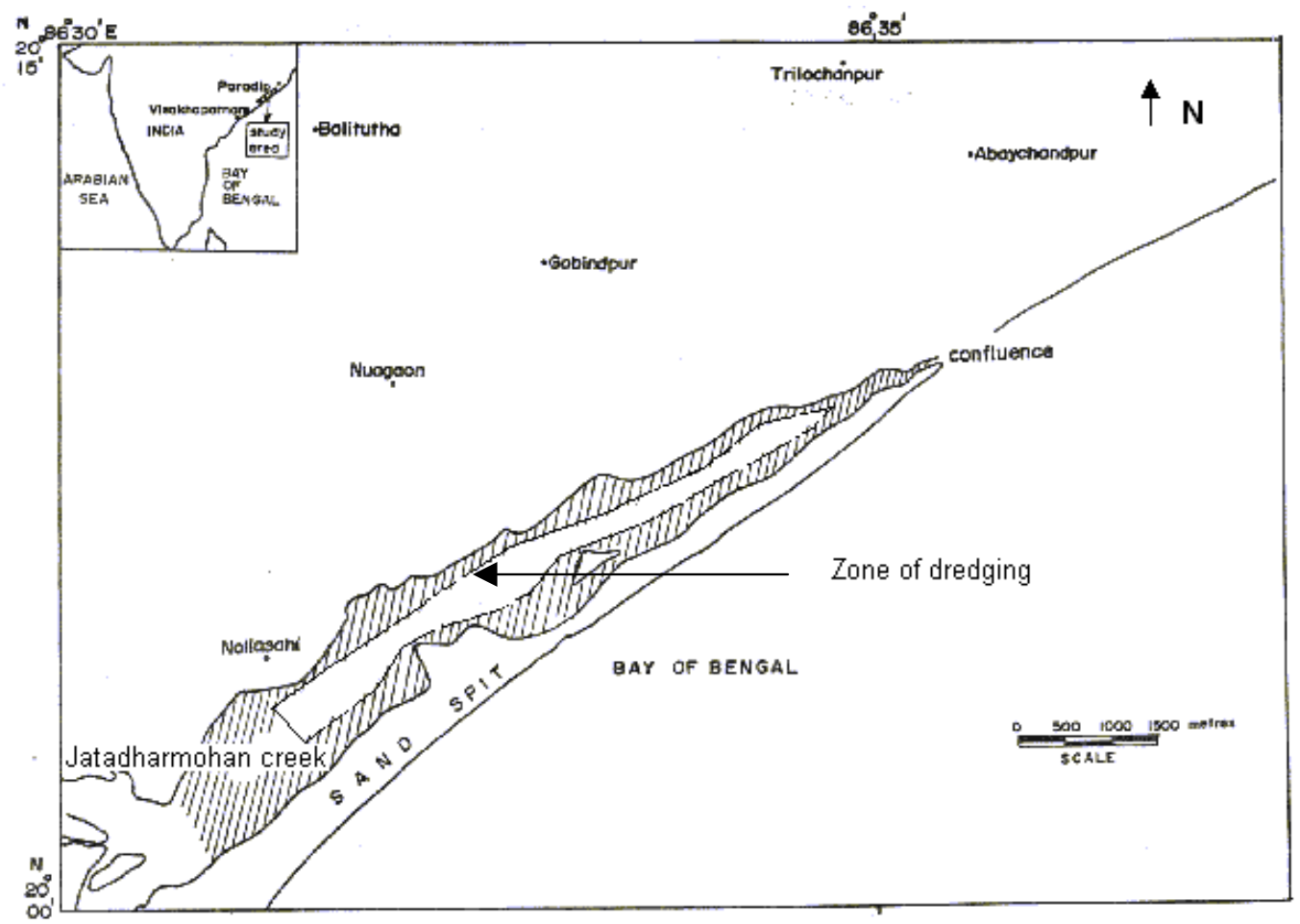

Fig. 1. Area of study 


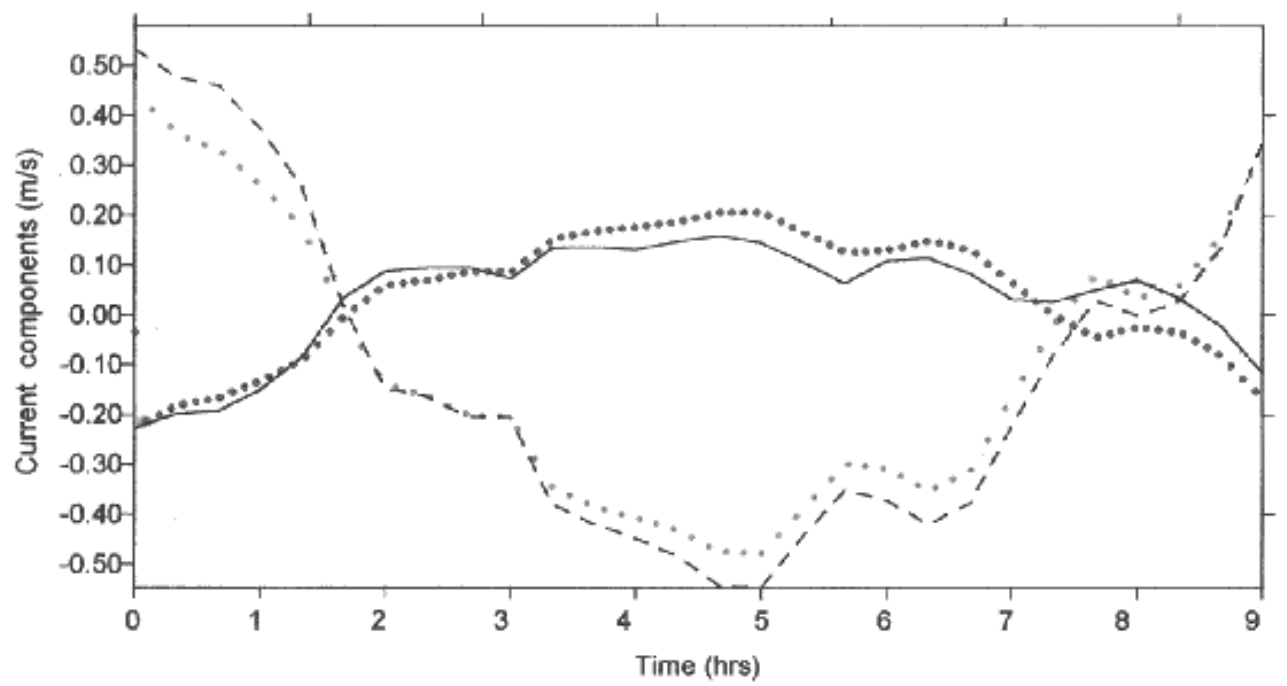

Fig. 2. Measured and modelled current components near the confluence point

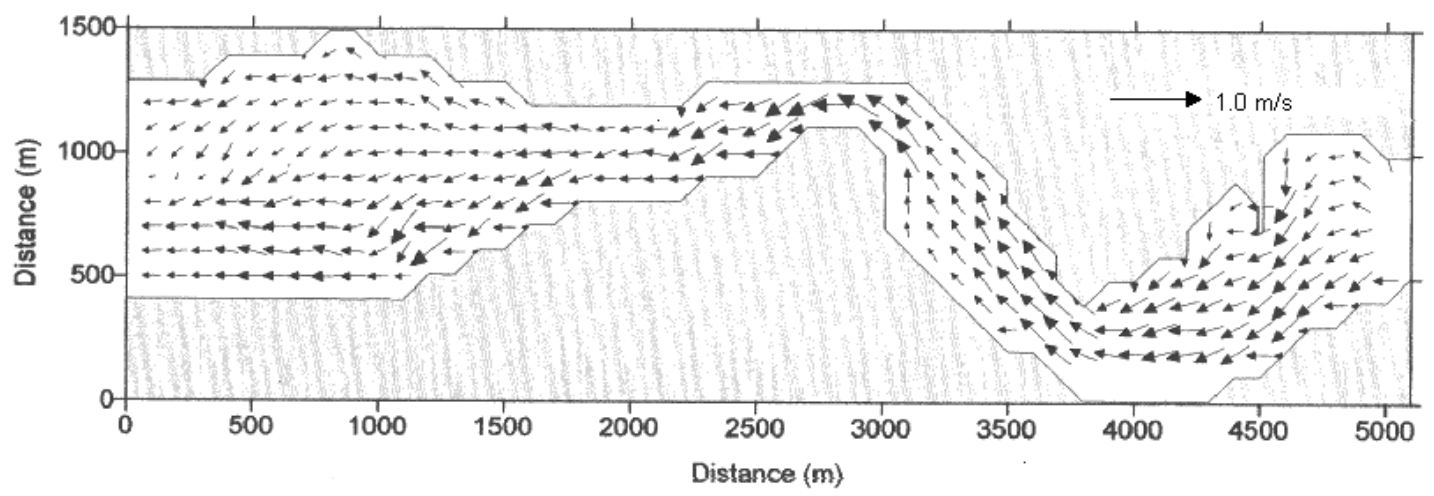

Fig. 3. Currents during flood tide for the existing bathymetry 


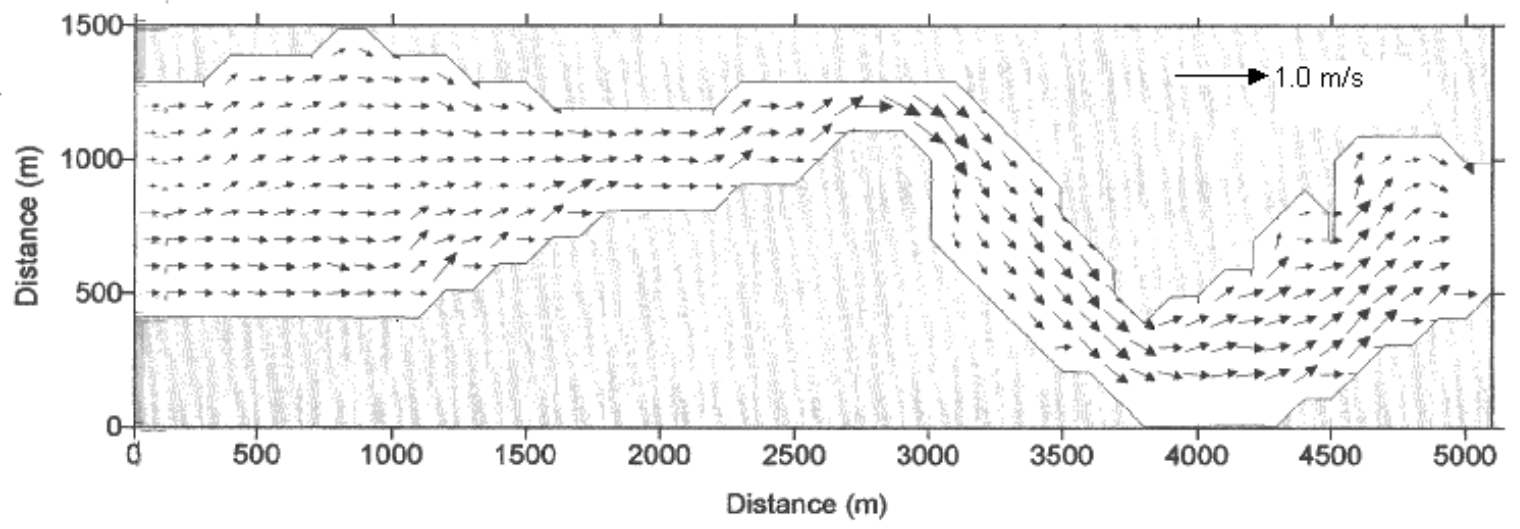

Fig. 4. Currents during ebb tide for the existing bathymetry

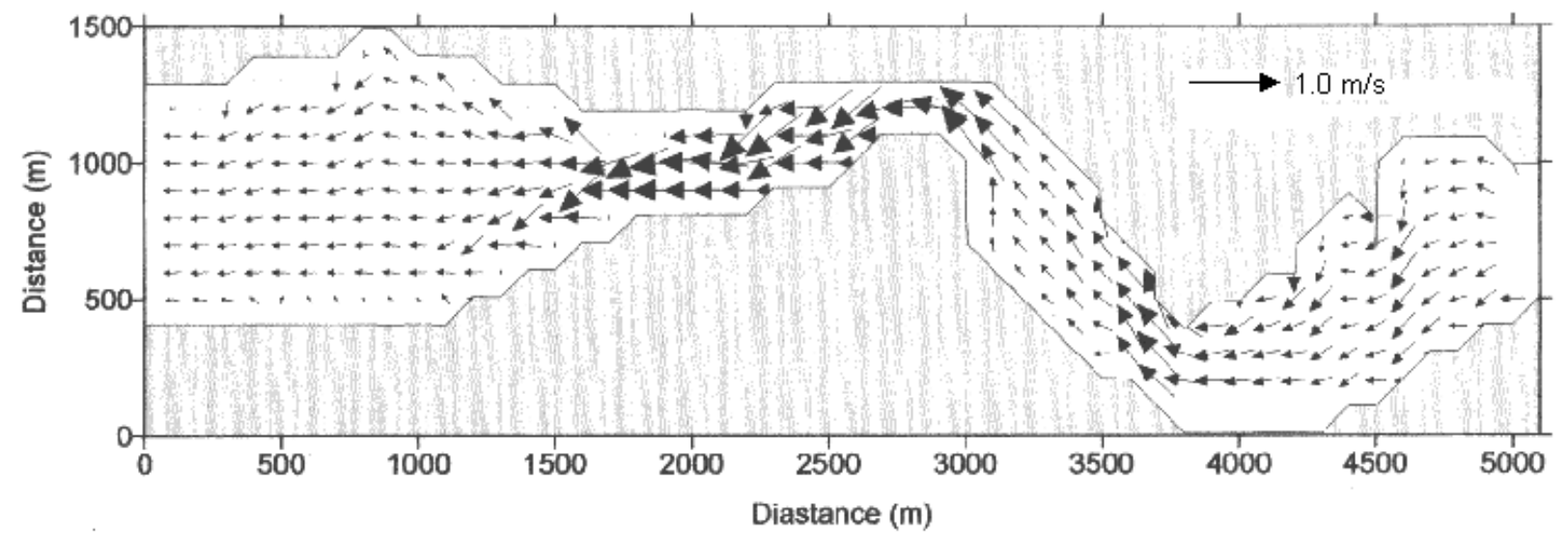

Fig. 5. Currents during flood tide for the new bathymetry (new depth $=$ original depth $+7 \mathrm{~m}$ ) 


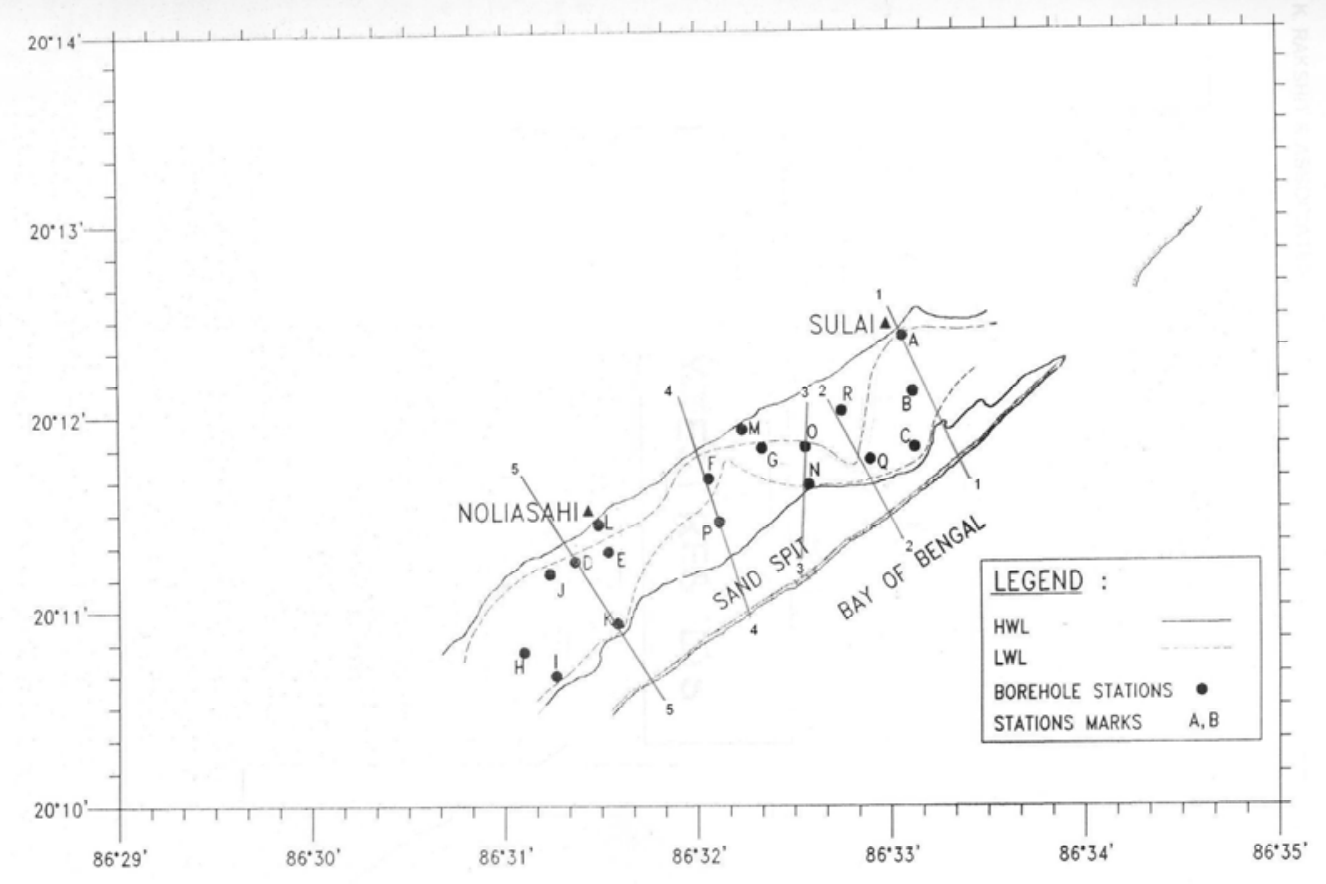

Fig. 6. Borehole locations and critical sections in the Jatadharmohan creek

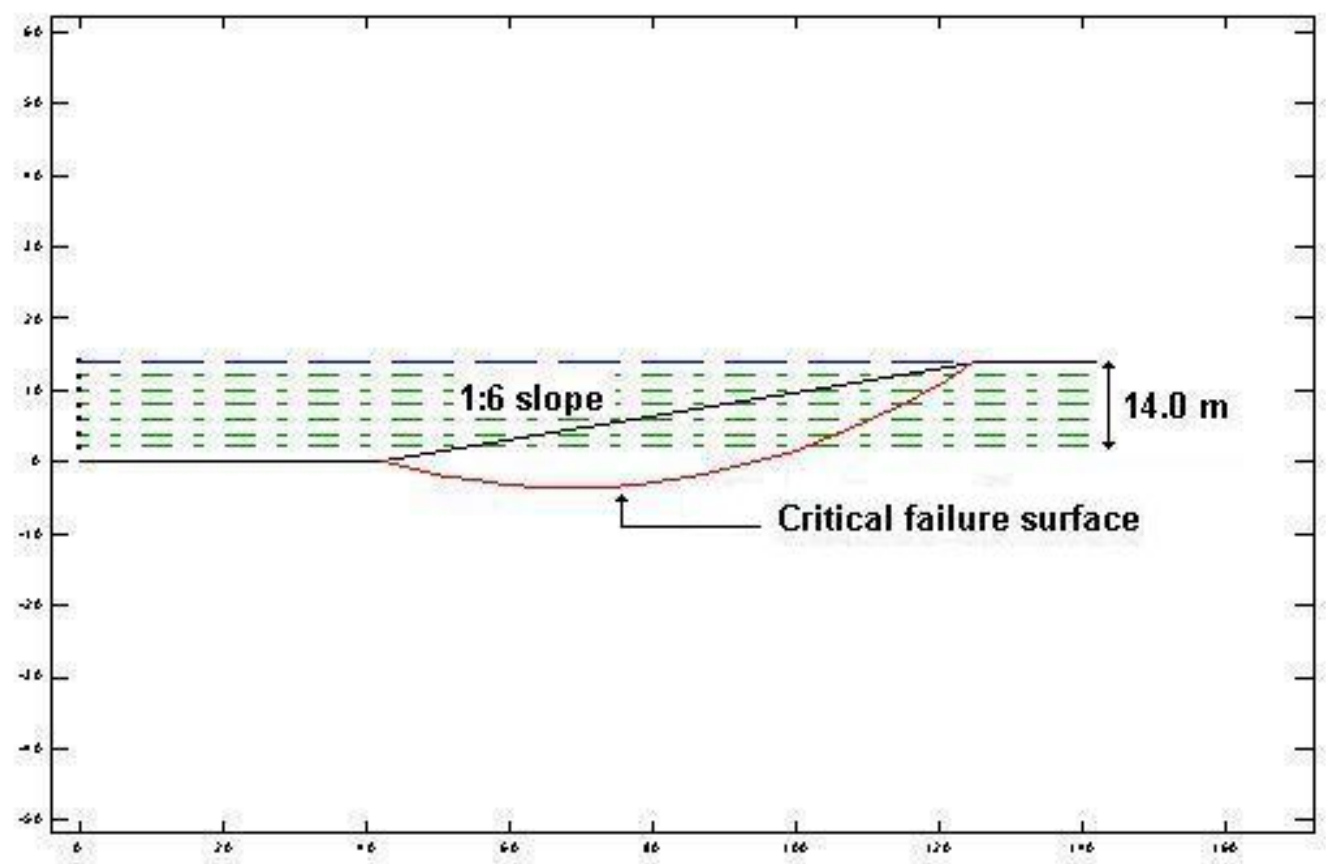

Fig. 7. Slope stability analysis at section 5 (critical factor of safety $=3.4$ ) 


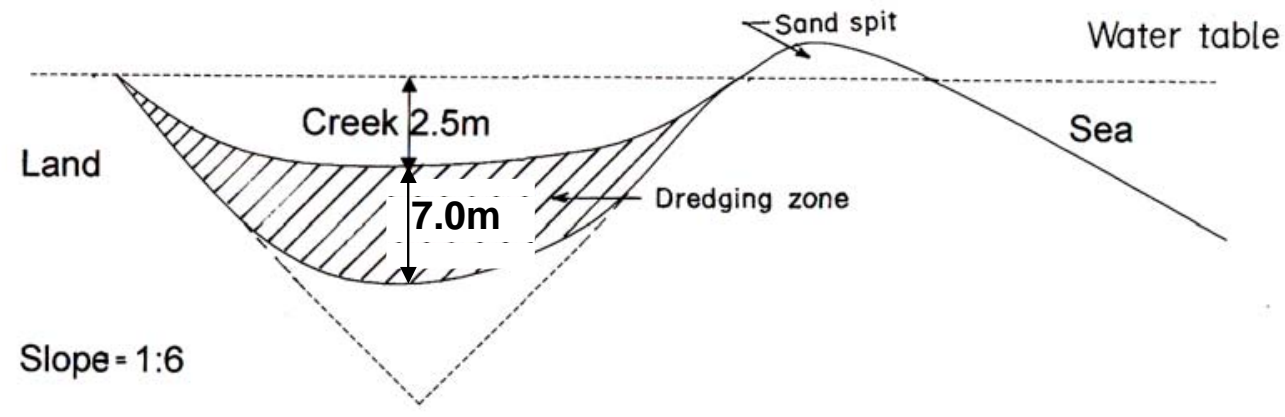

Fig. 8. Schematic diagram for hydrostatic stability (not to scale) 